\title{
Watershed-scale research from many perspectives-the Interdisciplinary Research Initiative at the Shingobee River headwaters area, Minnesota
}

Sound management of our Nation's water resources requires understanding of the fundamental physical, biological, and chemical processes that take place in watersheds. The Interdisciplinary Research Initiative (IRI) was established in 1989 to learn more about these processes, including how, when, and where they affect one another. In addition, the IRI was established to encourage scientists from many different disciplines to work together, address common waterresource questions from different perspectives, and gain new insights from the outlook, methods, and theories of scientists outside their own discipline.

A growing number of scientists from the U.S. Geological Survey (USGS) and from eight universities in five States continue to learn and discover more about these processes by studying a small watershed in north-central Minnesota. Results of this ongoing research are summarized in a recently released USGS Water-Resources Investigations Report titled Hydrological and biogeochemical research in the Shingobee River headwaters area, north-central Minnesota (Winter, 1997). This Fact Sheet presents some of the highlights in Winter, 1997, a 30 -chapter report.

\section{Lake processes-similarities and differences}

Because of its location in the lakes region of north-central Minnesota (figure 1), a primary focus of the IRI effort has been on processes associated with lakes. Seventeen of the 30 chapters contained in Winter, 1997, discuss

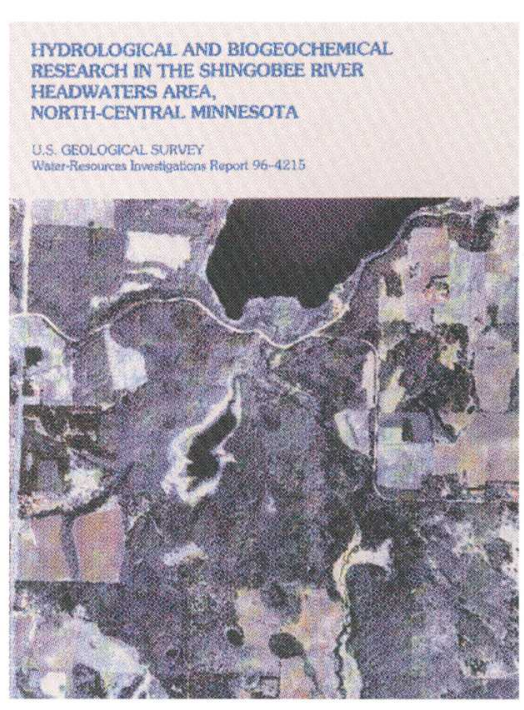

research related to processes in the IRI lakes. The IRI site was selected because it offered scientists the opportunity to study two distinctly different lakes in the same watershed, both small enough to allow intensive research that was practical and affordable. This approach allows scientists to learn more about processes that are unique to specific lake types and also those that are common to all lakes. Lakes were selected based on their "water residence time," or the time that it takes for all the water in the lake to be replaced by an equal volume of input from rainfall, ground water, and stream water. One of the underlying assumptions based on this study approach is that lakes having a short water residence time will be greatly
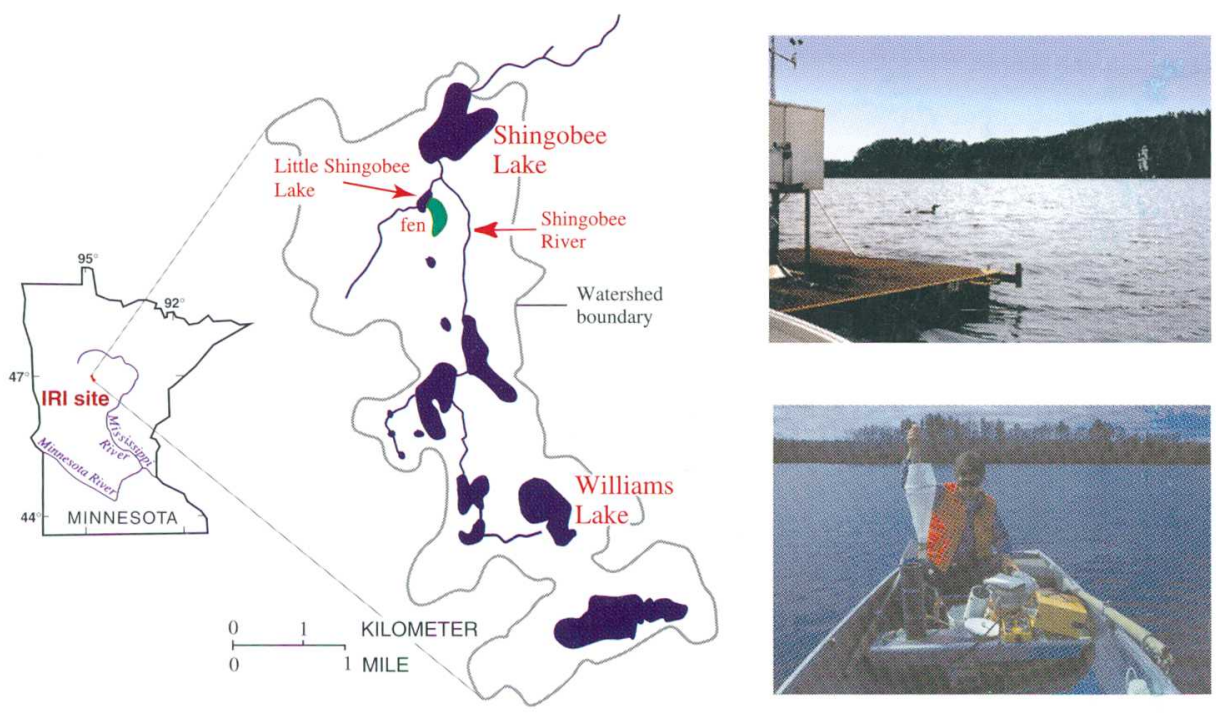

Figure 1. Research at the IRI watershed (2810 hectares, 6950 acres), located in north-central Minnesota, is concentrated at Williams Lake, Shinogobee Lake, the Shingobee River upstream of Shingobee Lake, Little Shingobee Lake, and a fen adjacent to Little Shingobee Lake. 
affected by water and chemical input from outside the lake, whereas lakes having a long water residence time will be more affected by chemical and biological processes that take place within the lake. Shingobee Lake has a relatively short residence time; the Shingobee River and ground water flush the lake volume about every 6 months. No streams flow to or from Williams Lake. Consequently, water in the lake is replaced only by ground water and precipitation; it takes about 3 years to replace all the water in Williams Lake (figure 2). Additional inter-lake comparisons are presented by Rosenberry and others (1993).

Williams Lake and Shingobee Lake are situated in substantially different physical settings even though they are located only 3 miles apart. Williams Lake is near the upper end of the Shingobee River watershed and is situated in poorly sorted glacial material composed primarily of medium to coarse sand. Numerous pockets of gravel, silt, and clay are mixed with the sand, making measurements of flow of water through the ground, both to and from the lake, challenging. Even with nearly 100 observation wells located near the lake, accurate determinations of fluxes between the lake and ground water remain elusive. Conservative chemicals and environmental isotopes also have been used to make reasonable determinations of the fluxes between ground water and the lake. In contrast, Shingobee Lake is situated in a deep topographic depression relative to much of the rest of the IRI watershed. Glacial deposits are finer and more uniform near Shingobee Lake, and they tend to become more coarse with depth. Ground water discharges to the lake on all sides, but the distribution of this discharge is focused in numerous springs located nearshore and beneath the lakebed. The combined ground-water discharge from springs is about one-third the flow of water into the lake from the Shingobee River and is nearly four times the flow of ground water into Williams Lake. Even though hydrologic fluxes to Shingobee Lake are dominated by streamflow, the large amount of ground-water discharge has a significant effect on the chemistry and distribution of aquatic plants in the lake.
WILLIAMS LAKE

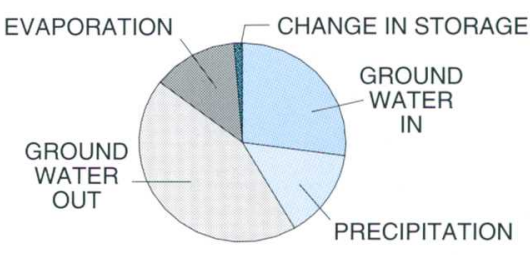

Total in $=165$

Total out $=226$

Change in storage $=-4.3$

\section{SHINGOBEE LAKE}

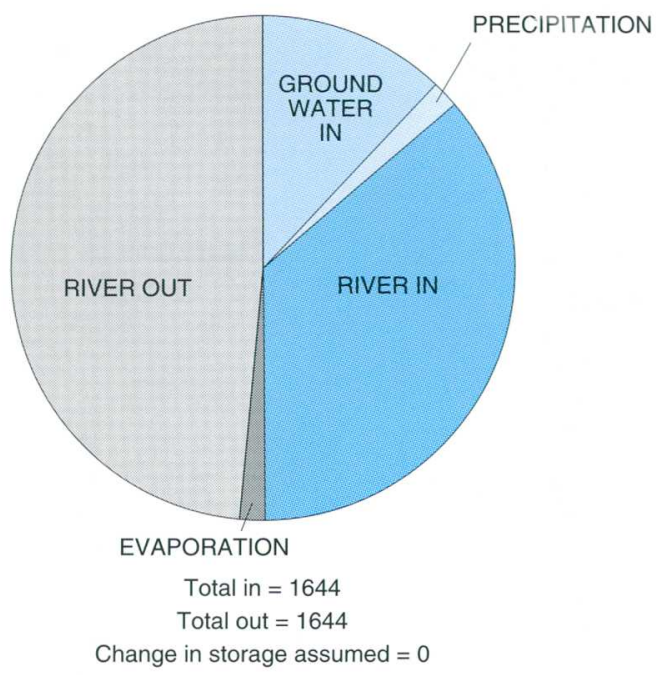

Figure 2. Average annual fluxes for Williams Lake and Shingobee Lake water budgets. (Pie size is proportional to total fluxes to and from each lake. Fluxes are in centimeters of water added to or removed from the lake surface per year.)

Lake and watershed managers commonly need to determine water and chemical budgets, and much of the work at the IRI site has focused on developing new methods for determining these budgets more accurately and economically. Traditional methods of determining budgets have been compared with new approaches at both lakes; some methods work well in one lake but not in the other. For example, the use of environmental isotopes has proven to be an inexpensive, reliable method for determining hydrological budgets for lakes that receive no streamflow such as Williams Lake, but the method is less robust for lakes that are flushed more rapidly with stream water, such as Shingobee Lake.

Another research emphasis at the IRI site has been the determination of carbon budgets for the lakes. Understanding and quantifying concentrations and transformations of carbon in the lakes, and fluxes of carbon to and from the lakes, will increase understanding of controls on lake productivity. This requires measurement of the carbon stored in lake water, in aquatic plants (figure 3 ), in lake sediments, as well as measurement of fluxes of carbon to and from the atmosphere, streams, and ground water. Atmospheric fluxes are of particular interest because of the potential for emissions of carbon dioxide and methane gases to increase the concentration of greenhouse gases in the atmosphere. Two different approaches for measuring atmospheric fluxes were compared at the IRI site, one requiring measurement of carbon concentrations in the lake water relative to the atmospheric concentrations (figure 4), and the other
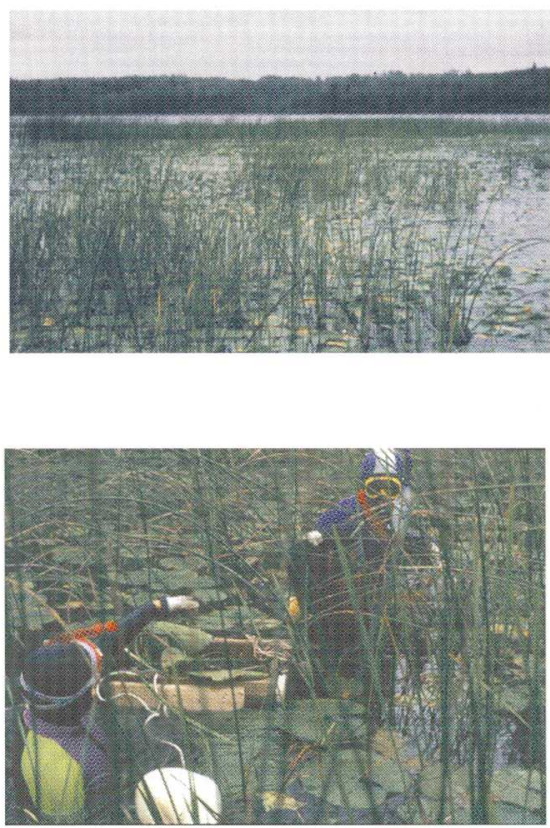

Figure 3. Biomass of aquatic plants contributes a significant portion to the carbon budget of Shingobee Lake. 


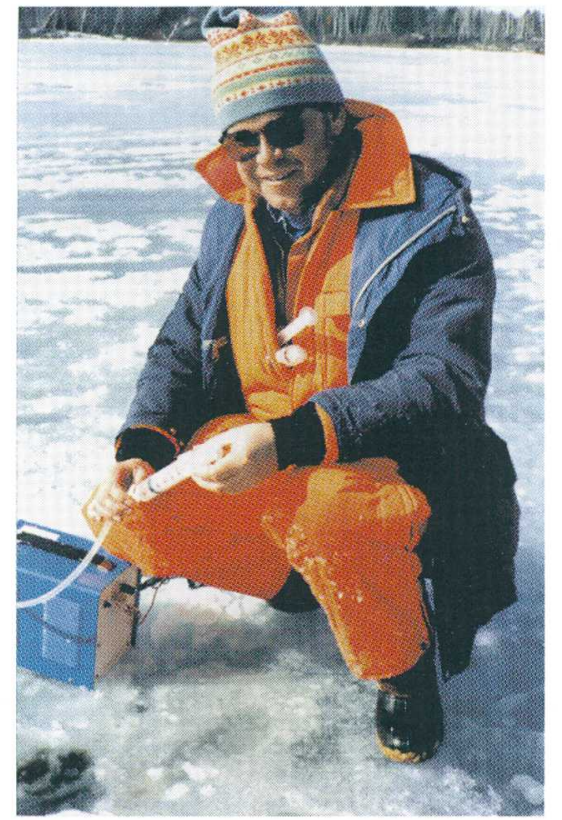

Figure 4. Collection of water sample through ice cover for determination of carbon dioxide and methane dissolved in the lake water.

requiring direct measurement of evaporation and carbon concentrations in the air directly over the lake surface (figure 5). Each method aided the other in determination of these fluxes. Measurements made during ice melt in April indicated fluxes of carbon dioxide were much higher than previously observed, and direct measurements using sensors mounted on a tower in the lake indicated higher fluxes to the atmosphere than fluxes measured by other methods (figure 6). In an interlake comparison of carbon fluxes from lakes in northern Minnesota, Striegl and Michmerhuizen (1998) have indicated that the relatively large concentrations of dissolved gases in Shingobee Lake are a result of the large flux of ground water to Shingobee Lake.

Sediments stored in the lakebeds provided a glimpse of the dynamic history of the IRI lakes. The suite of microscopic plants and animals that live in lakes changes as the lake depth, temperature, and chemistry change over time. Sampling of lake-sediment cores for remains of these organisms, as well as for pollen from plants that lived nearby, allows a reconstruction of past lake level and climatic conditions. About 9,800 years ago, both lakes were part of one much larger lake, "Glacial Lake Willobee," which covered most of the modern-day Shingobee
River headwaters area. Lake-sediment data, corroborated with evidence from the glacial geology in the area, indicate a sudden decline in the level of the glacial lake, perhaps the result of a catastrophic failure of an ice-core dam remaining after the latest glacial advance. During the 9,000 or so years following the draining of the glacial lake, Shingobee Lake level has changed very little. However, Williams Lake level has fluctuated at least $6 \mathrm{~m}$ in response to climatic changes recorded in the lake sediments. This information, along with the record of lake-level change, indicate that a lake having no surface-water inflow or outlet is much more susceptible to changes in climate, even when the lake is well connected with ground water.
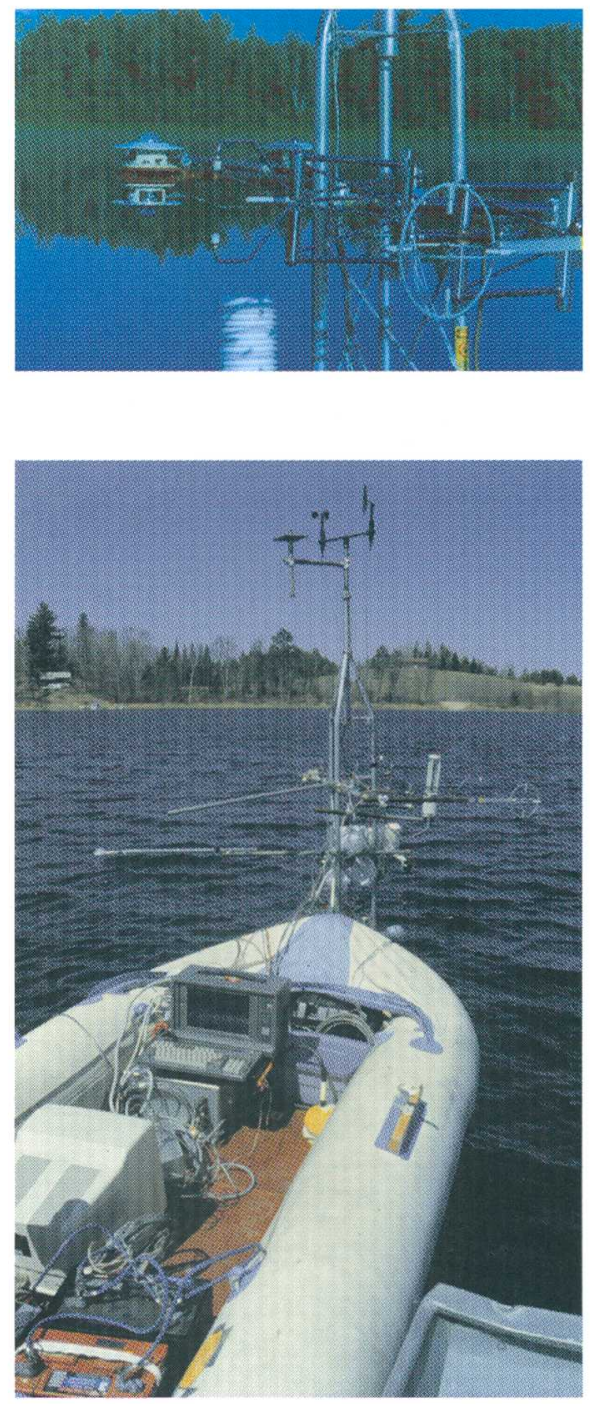

Figure 5. Measurement of evaporation and carbon flux using the eddy-correlation method requires a stable platform such as this tower installed near the center of Williams Lake.

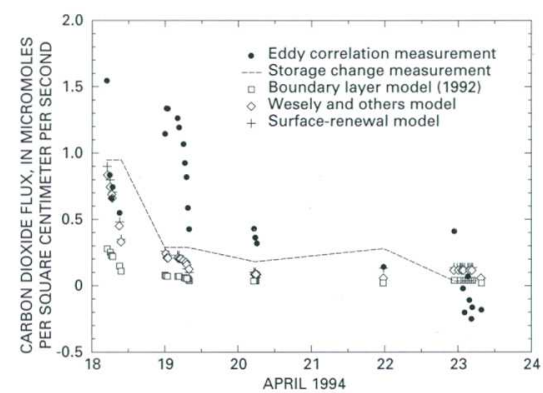

Figure 6. Comparison of different methods for determining the flux of carbon dioxide from Williams Lake immediately following ice melt in April.

\section{Streamflow processes- research in the hyporheic zone}

The hyporheic zone, located directly beneath and adjacent to a stream, where water flows back and forth between the stream and its streambed and streambanks, is eliciting much research interest worldwide. Processes that take place in the hyporheic zone can greatly affect the chemical and biological composition of the stream. The hyporheic zone of the Shingobee River upstream of Shingobee Lake is thinner than that of many other streams, most likely because significant ground-water discharge compresses the zone to the top 10 to $20 \mathrm{~cm}$ of streambed sediments (figure 7). Detailed flow measurements along a 1,200-m long reach of the Shingobee River indicate that ground-water discharge increases the river flow by 20 percent, averaging 1.8 liters per minute per meter of stream reach. This discharge was found to be highly localized; at some locations water dislodges and suspends sand as it discharges to the river. Groundwater discharge generally is concentrated downstream of steeper sections of the river.

Hydrological, chemical, and biological processes that take place in the top $20 \mathrm{~cm}$ of the river-bed sediments are reported in four chapters in Winter, 1997. Among the results presented are the findings that nitrification/ denitrification processes lower the concentration of dissolved inorganic nitrogen in the stream water, which affects the plants and animals living in the stream. This process also decreases the loading of 

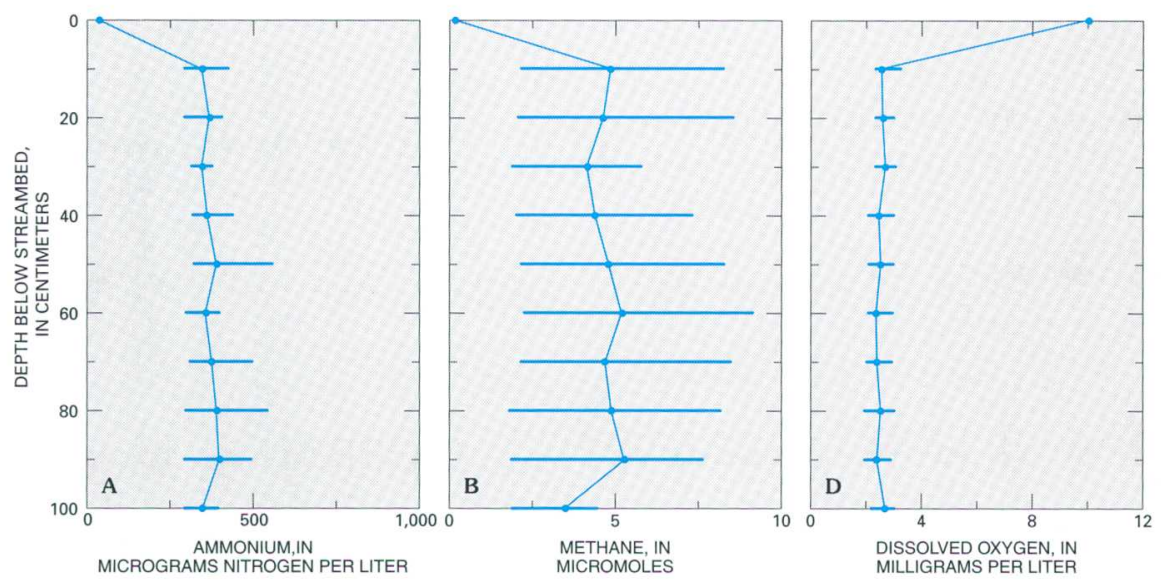

Figure 7. Chemical profiles from the hyporheic zone beneath the Shingobee River.

nitrogen to Shingobee Lake, which affects the biological community living in Shingobee Lake.

\section{Wetland processes- a productive fen}

A forested wetland in the IRI watershed (figure 8) displays many species of exotic plants, including pitcher plants, sundews, yellow lady slippers, pink lady slippers, and showy lady slippers. This wetland, defined as a fen because it is dominated by continuous ground-water discharge, became a focus of research because of its unique hydrological and biological setting, and because scientists found that it was critical to determine the source of such a large volume of ground water. The source of water contained in numerous small pools in the fen colonized by iron bacteria also needed to be determined. Research on this fen is reported in four chapters in Winter, 1997. Most of the ground water likely originates from recharge at uplands east of the Shingobee River and perhaps west of Little Shingobee Lake; discharges at the eastern, upper margin of the fen; and flows overland across the fen to several small streams that drain into Little Shingobee Lake (figure 1). The water in the fen is primarily calcium bicarbonate, has a $\mathrm{pH}$ of 7.4 to 7.8 , and generally increases in sodium and chloride content to the west, indicating some concentration of solutes resulting from evapotranspiration. Cores taken from the fen indicate that during the past 10,300 years it has been transformed from an open lake at least $17 \mathrm{~m}$ deep to a primarily forested wetland composed of peat covered by a sphagnum-moss veneer.
Figure 8. This forested fen receives a uniform, large discharge of ground water aquatic plants. that provides a stable environment for rare
This Fact Sheet presents only a small part of what is covered in Winter, 1997. Many of the research efforts are in their infancy and only now are addressing the questions that will advance knowledge of watershed-scale processes. To date (7/98), 28 papers related to the IRI effort have been published in journals and USGS publications. An updated list of IRI-related reports can be found at http://water.usgs.gov/ lookup/get?crresearch/projects/IRI.

Research continues at the IRI site, and investigators with a cooperative spirit and an interdisciplinary interest are invited to join the effort.

\section{References Cited}
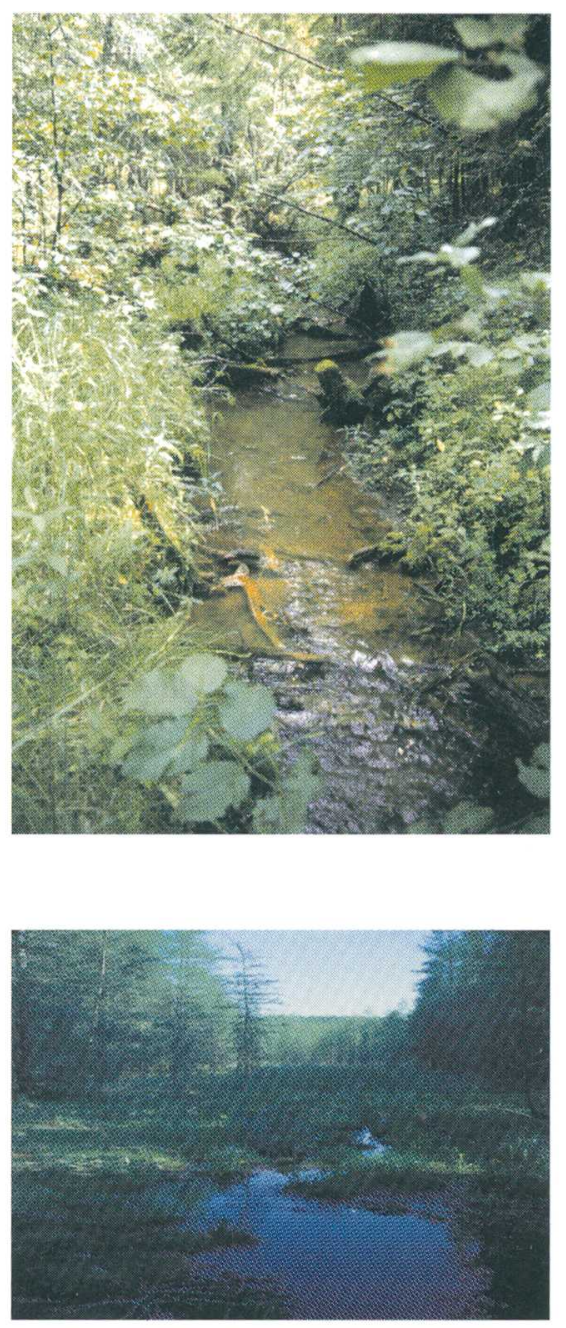

Rosenberry, D.O., LaBaugh, J.W., McConnaughey, T.A., Striegl, R.G. and Winter, T.C., 1993, The interdisciplinary research initiative: hydrologic research in the Shingobee River headwaters area, Minnesota: U.S. Geological Survey Open-File Report 93-446, $2 \mathrm{p}$.

Striegl, R.G., and Michmerhuizen, C.M., 1998, Hydrological influence on methane and carbon dioxide dynamics in two north-central Minnesota lakes: Limnology and Oceanography, vol. 43.

Winter, T.C., 1997, [ed.], Hydrological and biogeochemical research in the Shingobee River headwaters area, northcentral Minnesota: U.S. Geological Survey Water-Resources Investigations Report 96-4215, 210 p.

\section{—Donald O. Rosenberry}

For additional information contact:

Chief, Branch of Regional Research

U.S. Geological Survey

Box 25046, Mail Stop 418

Denver Federal Center

Denver, Colorado 80225 